\title{
"If Things Really Go On as They Are at the Moment, Then I Will Work Illegally. End of Story." Pandemic Realities in Marginalized Entrepreneurships
}

\author{
Markus Tümpel \\ Chemnitz University of Technology, Germany \\ Pia Cardone \\ HR Manager, Chemnitz, Germany
}

DOI: https://doi.org/10.18778/1733-8077.18.1.04

Keywords:

Entrepreneurship;

COVID-19;

Biographical Study;

Autonomy; Narrative

Approach; Sex

Workers; Fitness

Instructors; Clothing

Stores; Caterers

\begin{abstract}
Micro-enterprises and self-employed individuals have been hit particularly hard by the economic effects of the COVID-19 pandemic, but few studies have tackled the issue. This paper is based on four in-depth case studies of self-employed people from different sectors who have been greatly affected by measures taken to control the pandemic. By capturing shifts in the perception of institutional and economic pressures, as well as precarity after the outbreak of COVID-19, we gained profound insight into crisis management among entrepreneurs working in niche or marginalized fields of business. We found parallels in their biographies and attitudes, but their perceptions of the COVID-19 pandemic differ. We observed paradoxes and hybrid logic, as well as different ways of coping with the crisis. Having a "plan B" helped in some cases, while all of them benefitted from the solidarity of networks and communities.
\end{abstract}

Markus Tümpel is a Research Associate at the Chemnitz University of Technology at the Faculty of Economics and Business Administration. He completed an MA in Sociocultural Studies and is currently working on his Ph.D. His fields of research are self-employment and precariousness, participation, deviance, and alternative forms of organization. He recently co-authored a study on participation practices in German cooperatives.

email address: markus.tuempel@wirtschaft.tu-chemnitz.de
Pia Cardone holds a Ph.D. in Economics and works as a Manager for HR and Organizational Development. Her main research interests, shaped during her time as a Research Associate at the Department of Organization and International Management at the Chemnitz University of Technology, include social inequality, effects of intra-organizational figurations, and processes of inclusion and exclusion in organizations. Her research follows an interdisciplinary approach represented in publications and conference contributions in the fields of sport sociology, migration, and management research. 


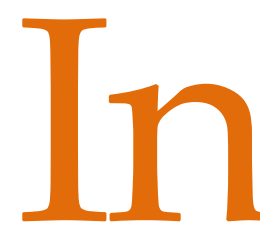

spring 2019, we began a study of self-employed individuals and freelancers to explore "deviating biographies." We were interested in people whose biographies and personalities largely diverge from the stereotype and archetype of the "successful entrepreneur," which have been criticized for quite a while (e.g., Gerpott and Kieser 2017; Johnsen and Sørensen 2017). However, after we collected a considerable amount of data on four individual cases, COVID-19 emerged. The pandemic changed the working routines and lives of people across the world and impacted our investigation. By accident, our sample of four cases included entrepreneurs in professional fields that were severely restricted by measures taken to contain the COVID-19 pandemic. We soon realized that we should capture this disruption. Hence, we added another round of data collection to the existing individual case studies, (re-)setting the focus on recent developments.

Therefore, the aim of our study evolved to capture shifts in the perception of institutional and economic pressures, as well as precarity after the outbreak of the COVID-19 pandemic, and gain profound insight into crisis management among entrepreneurs working in niche and marginalized fields of business. The research questions are as follows:

R 1: Are there specific ways of reacting to the new constraints and requirements imposed by various interest groups during the COVID-19 pandemic? If so, what are they?

R 2: How are new institutional demands experienced in these specific fields of business, and how is reality individually framed or constructed in the context of COVID-19?

Although nearly every sector of the economy has been affected by the crisis, micro-enterprises, self-employed individuals, and entrepreneurs have been hit particularly hard (Cepel et al. 2020; Fabeil, Pazim, and Langgat 2020; Fairlie 2020; Kartseva and Kuznetsova 2020). Depending on the sector, they have faced a total loss of earnings or extremely precarious conditions. Initial studies conducted in different countries and regions have dealt with how these groups coped with the crisis (Bartik et al. 2020; Blundell and Machin 2020; Shafi, Liu, and Ren 2020); however, only a few of these studies have adopted a qualitative approach (e.g., Rukti Tanaya and Ekyawan 2020; Wijaya 2020). Shepherd and Williams (2020) emphasized the need for studies focused on entrepreneurial activities in the context of the current crisis, especially as it relates to individual resilience. The role of resilience for entrepreneurs and ways of responding to precarious and uncertain circumstances seem to be very prominent matters among scholars who have conceptualized and called for studies on the ongoing crisis and its impact on entrepreneurship (e.g., Hite and McDonald 2020; Portuguez Castro and Gómez Zermeño 2020; Ratten 2020). This is why our study focuses on how entrepreneurs are responding to and coping with economic and social burdens during the COVID-19 pandemic.

\section{Theory}

Given the strong institutional pressures and demands on business owners resulting from measures and regulations enacted to control the spread of COVID-19, we propose approaches of new institutionalism as a theoretical perspective to frame the analysis and acquire knowledge about current events. The neo-institutionalist approach claims that organizations adopt dominant practices of other-successful-organizations (DiMaggio and Powell 1983). Following the original approach, institutionalized "techniques" and "policies" are strong 
myths that organizations are forced to implement (Meyer and Rowan 1977:340).

Taking this as a basis, studies on organizational responsiveness and organizational logic help to understand how various institutional pressures embodied in regulations, norms, laws, and social expectations stemming from various sources, such as the state and public or private interest groups, are managed (Delmas and Toffel 2008; Greenwood et al. 2008; Greenwood et al. 2011). The COVID-19 pandemic and the urgency of containment have led federal and regional authorities to impose numerous constraints, such as regulations on social distancing, border closures, the prohibition of mass events, and the temporary closure of numerous businesses during the lockdown. Additionally, social expectations regarding business policies focused on protecting the health of employees and customers have risen. The new prioritization of health protection logic represented by institutions, such as the state and community, has led to criticism of organizations that failed to protect their employees, knowingly endangered them, or caused outbreaks (e.g., at Tönnies meat processing factories ${ }^{1}$ ). This not only illustrates the increasing public pressure but also shows how questions of mismanagement and resulting precarity can enter the discourse.

Studies have shown that organizations develop diverse strategies to respond to their environment, and not all organizations experience institutional demands in a given field in a similar way (Oliver 1991; Kraatz and Block 2008; Greenwood et al. 2011; Crilly, Zollo, and Hansen 2012). Moreover, an institu-

\footnotetext{
${ }^{1}$ In June 2020, a major outbreak of COVID-19 occurred in one of Europe's largest meat processing plants in RhedaWiedenbrück. Its primary causes were the catastrophic and unhygienic working and living conditions for the workers, most of whom are migrants (Deutsche Welle 2020; Paul 2020).
}

tional perspective in research on entrepreneurship is well established and proven to be helpful (Bruton, Ahlstrom, and Li 2010; Su, Zhai, and Karlsson 2017), and some qualitative studies have taken this stance (e.g., Eijdenberg et al. 2019). By drawing on this theoretical framework, the current study takes a micro-perspective focused on individual behaviors and mindsets (e.g., Wicks 2001). This approach will provide new insights into the perceptions and reactions of entrepreneurs in fields of business strongly affected by COVID-19 pandemic-imposed institutional pressures and suffering economic precarity. Thus, this study contributes to the evolving scientific discourse tackling the questions arising due to COVID-19 from a managerial viewpoint (Hite and McDonald 2020; Spurk and Straub 2020).

In addition, several studies have begun to examine the identities of entrepreneurs (e.g., Leitch and Harrison 2016), including research on conflicting identities (e.g., Pécoud 2004; Slay and Smith 2011; Schediwy, Bhansing, and Loots 2018) and hybrid ones, for example, within the context of migration (e.g., Essers and Benschop 2007; 2009; Barrett and Vershinina 2017). Since our study follows a narrative, biographical approach, identities also play a role here (Czarniawska 2004; Ozasir Kacar and Essers 2019), and concerning the field of "non-typical entrepreneurs," questions of identity formation may arise. As Laclau (1990:39) concludes, "every identity is dislocated insofar as it depends on an outside which both denies that identity and provides its condition of possibility at the same time." By drawing on this notion, this paper also seeks to trace facets of individual identities.

\section{Data and Method}

Our research design is a multiple case study (Stake 2013; see also: Eisenhardt and Graebner 2007; Yin 
2018) based on four in-depth case studies of self-employed people from different sectors: a fitness instructor, who is also the owner of a CrossFit gym; the head and founder of a catering company; a retailer and importer, who owns a small clothing store; and a sex worker, who also works as a sexual assistant. All four case studies focus on people who run their business in the eastern part of Germany and belong to two cohorts of the so-called Wendejugend (the youth of the transformation) and Wendekinder (children of the transformation). These individuals were born during the former German Democratic Republic (GDR) between 1971 and 1980 or 1981 and 1985 (Ahbe and Gries 2006a; 2006b; Kubiak and Weinel 2016; Lettrari, Nestler, and TroiBoeck 2016). All of them spent most of their adolescence during the final years of the GDR or the years of transformation during the 1990s. Hence, they all share the experience of ruptures and fluctuations in the course of the transformation or its results. To date, numerous studies have investigated the distinctive characteristics of these generations (Bock 2000; Lettrari, Nestler, and Troi-Boeck 2016; Kubiak 2020) but also raised the question of whether these generations have common features (Benkert 2016). A broader perspective was adopted by Banalieva and colleagues (2017), who argued that the longterm effects of communist societies on individual behavior continue to the present day and, for instance, shape management practices (see also: Vadi 2018). Other authors have examined the transition of East German identities after the reunification with West Germany, focusing on somewhat marginalized Eastern German perspectives (Maclean, Harvey, and Stringfellow 2017).

Our study focuses on entrepreneurs by accident (Sarasvathy 2001; Görling and Rehn 2008) and the so-called "necessity entrepreneurship" (Brewer and
Gibson 2014) within this context (see, e.g., Welter, Smallbone, and Isakova 2006; Blokker and Dallago 2017). We followed the four cases over a period of 18 months, starting in spring 2019. We conducted multiple interviews, as well as participatory observation and shadowing. We had the unique opportunity to directly accompany self-employed people dealing with the crisis in "real-time." We used the autobiographical-narrative interview approach (e.g., Schütze 1983) and extended it by splitting the interviews into two parts to stimulate people's reflexivity between sessions and make it possible for us to prepare for the second session based on the first, which supports sociological reflexivity (Caetano 2015). This procedure allowed us to capture people's reflections on the ongoing pandemic and doing business under these circumstances.

A special feature of this study is access to the field and respective sampling. We were able to draw on personal contacts and thus a sense of trust. The selection of cases was, therefore, also based on pre-existing (while fragmentary) knowledge of their biographies, or at least the knowledge that their biographies and, perhaps, their intentions differ considerably from those of a "prototypical" entrepreneur. Thus, they "fit" the original aim of our inquiry in its focus on biographies deviating from the "prototypical" entrepreneur. We used MAXQDA and followed an inductive approach to analyze all the transcripts and documents. Nonetheless, our theoretical lens sharpened the focus on response strategies and interpretations of entrepreneurs concerning the COVID-19 pandemic. Consequently, in the discussion of the results, we will draw on approaches of new institutionalism. Based on the coding and respective categories, comprehensive case descriptions were elaborated, and triangulation was used (Patton and Appelbaum 2003; Den- 
zin 2009; Flick 2011; 2018; Stake 2013; Natow 2020). Both authors were equally involved in the analysis, and their interpretations were discussed regularly (Stake 2013; Kuckartz and Rädiker 2019). In the next section, we will present our four cases in detail, focusing on their biography and the effects of the COVID-19-pandemic.

\section{Results}

\section{Case \#1: Tom}

Tom was born in 1981 in the former GDR and grew up with two siblings. He is interested in many things, which are reflected in his biography. In early childhood, he was active in sports. Contrary to his ambitions, his school career ended early: "I was...very sad when I had to leave school. That was, as one would say today, chicanery by the school management, or it was just a lack of motivation." He then began an apprenticeship as a carpenter and discovered his passion for woodworking. After a phase of burnout, he decided to take a break and traveled to the Philippines. What started as a holiday in Asia ultimately became nine years of his life. After returning home from the trip, he immediately quit his job, sold his property, and returned to Asia. In the Philippines, he met his former partner and entered the hotel business, where his training as a carpenter gave him a foothold. His way of working and his ideas were well received, and he was promoted to general manager of the hotel within three years.

After the hotel was slated to be sold, Tom and his partner decided to go to Australia. Drawing on their contacts with boutique owners and manufacturers, they set up a business engaged in importing accessories from Asia. This was a great success: "It was really fantastic. During the sales weeks, I drove two and a half thousand kilometers every week across Australia, so it was really great." During this period, Tom tried to visit Germany once a year. One summer, he arrived home just as his father became ill. After returning to Australia, he received word that he died. The early death of his father prompted him to return to Germany, as he wanted to support his mother. He separated from his partner and left all their joint businesses to her. However, the financial loss did not seem to make him feel bitter, and this stance illustrates his general attitude quite well:

When I left Australia, I left a relatively large amount of cash behind. It was clear to me that I would never go back...I liked working there, and I liked the life there, but I did not care about the money.

In Germany, Tom had to build a new life for himself, without money or his partner. Living on his parents' farm, he had no major expenses. Based on his experiences in Asia, he began working in the hotel business again while also working as a personal trainer. Looking for a new challenge and passion in his life, he thought about CrossFit, a sport he discovered abroad and a megatrend that had not yet arrived in his hometown. His training space, the "CrossFit-Box" as it is called, is very important to him, and he invested all his money and time in the project.

In explaining his motivation, he describes himself as a person who had a lot of luck in life, which he would like to share with others. His travels and various activities equipped him with a lot of experiences, for which he seems grateful. The CrossFit-Box is run as a non-profit business, where he gains satisfaction from doing something he likes to do and getting positive feedback from clients. 
My profit is when I make people fit, my profit is when I make people healthy, my profit is when people like to come to me. And that was also a criterion for me, why I said, “Ok, I don't offer memberships.” Because I really want to see that people want to be here! If someone doesn't want to be here, then I don't want his money either.

As he shows little interest in material possessions, he also has a less capitalistic view on work and entrepreneurship. Money seems of little value to him:

What do I do with the money when I get it? I have no children, I have no family, I own my property, all I have is mine. Why should I make money with it? I don't know what to do with it.

His motivation is also driven by the search for new challenges, even if they are risky. Due to his experiences in Asia and Australia, he is used to dealing with major changes. He describes traveling as giving him "the courage to risk things." He is not afraid to leave things behind and start over; if a business model does not work, he does not consider it a failure but a "sign that brings something new with it." For him, it is not important to be self-employed or to earn a lot of money per se, but he emphasizes that it is a matter of doing what you like to do on a professional level. In his opinion, people should ask themselves the following:

If the money is worth nothing anymore, are you in the situation where you would like to be, or have you chosen the wrong way? Because if you do that from the beginning, then no matter what happens to the business, no matter how bad your income is, you are always on the winning path. You are always happy... You are good at what you do, you get good feedback, and that's it.
With this positive attitude towards life, his interpretations of economic restraints and challenges are positive. His stance also seems to have helped him throughout the COVID-19 pandemic so far. Tom's gym, his training space, had to close down abruptly, as did similar businesses. Nevertheless, he benefited from his strategy of hybrid entrepreneurship: always relying on hybrid forms of income, including wage jobs and self-employment. Though this is not necessarily a distinctive aspect of COVID-19, it is important as a "backup" in precarious times:

That exact situation is why I kept the workshop for years, why I stayed at the hotel part-time for years if ever such a situation comes up. That it [the business] is just not over all of a sudden, right?

Although his turnover is zero, he saw no reason to worry about his finances. This is why Tom did not apply for any funding or loans, which he generally perceives critically. In his opinion, the state will reclaim much of the disbursed COVID-19 aid after audits have been completed. In his opinion, this will cause severe problems for many small businesses.

Moreover, Tom seems to have been well prepared in terms of logistics and what was about to come in the winter and spring of 2020. According to Tom, he relied on personal contacts in Asia, who gave him updates on the pandemic, so he took the situation seriously from the outset. Assuming that the pandemic would reach Europe soon, he started to prepare online tutorials in January 2020. Throughout the "first year of the pandemic," Tom was constantly adapting to the situation and found alternative solutions (e.g., outdoor training sessions). However, the changes are mostly temporary, and he does not consider them to be long-lasting business developments (e.g., digital sport offers a temporary solution 
but does not fit his concept of personally assisted training and direct contact to the workout group). Solidarity, networks, and the support of friends and customers helped considerably. His customers continued to pay their fees for training sessions even though they could not take place. However, people who could not afford to pay for lessons or equipment rental fees were not obliged to do so. In addition to online lessons, he offered personal meetings, especially for people in need or difficult circumstances. In an interview in summer 2020, Tom states the following:

It must go on now...and, um, since this month, we have been going on step-by-step in small groups. Um, sluggish, challenging, and so on. But, yes, I say, if it goes on now, if no second wave comes now, or if we don't have to go back or whatever, um, it wasn't that hard for me.

His rather positive baseline might have led Tom to frame the COVID-19 pandemic as an opportunity to slow down his routines (like another case, Hans, the caterer):

What I liked about the whole thing was that it was all slowed down. At first, everyone just stopped, stayed at home, stayed calm, stayed...no fear of missing something or feeling the need to go somewhere. I don't think that was so bad. That brought us a little bit back to the basics, you know?

As a matter of principle, Tom is in favor of adopting measures to prevent the spread of infection. He criticizes both imprudent and irresponsible behavior. After all, he also considers his branch to be in danger and pleads for more caution:

That's also what I told my people: "We better do a little too much. Um, the worst thing that could happen to us is that someone gets infected, that someone gets sick or has long-term damage, or worse ((clears throat)). We have all ages, from five to 65 ...or that sports are completely stopped."

Again, his rather "cosmopolitan" perspective seems to have shaped his judgment. Perceiving the crisis as a global rather than an individual problem may lead to the greater acceptance of measures and restrictions: "I've considered this to be a worldwide problem, right from the beginning." His stance towards the reality of the pandemic is even more interesting when compared to questions of regulations and bureaucracy in Germany. When talking to him almost one year before the COVID-19 outbreak, he drew comparisons with Asia and Australia, stating that in Germany, it is difficult for founders who want to comply with all guidelines and regulations: "If you try to stick to any guidelines we have in this country, then you won't get anywhere." His compliant position on corona, however, may be due to his anti-materialistic and people-centered values. He is very aware of the seriousness of the infectious disease and the resulting problems for those affected, and he is happy to accept business shortages in return. In contrast, he shows a rather indifferent attitude towards other regulations, perceived as "pointless" and simply a way of over-bureaucratizing processes.

\section{Case \#2: Hans}

Hans was born in the early 1970s and grew up during the GDR. As a teenager, he was sent to a "reform school" (Jugendwerkhof) known for the inhumane and degrading treatment of its juvenile inmates. After his release, he worked for VEB Kombinat Robotron, which was the largest computer manufacturer in the GDR at the time. His youth, family 
background, and possible experiences of repression seem to have had a significant impact on his career:

Well, I went through several factories in my youth. With... ((pauses 4 sec.)) some rather unpleasant... ((3 sec.)) uh... situations, or circumstances... where it was clear to me at some point... that I would not end up in any factory. I mean, well, that's actually a result of... you'd have to go back as far as into the family and how things were in the GDR and how... how circumstances led to the way I developed.

After East and West Germany were reunited, Hans joined the local punk scene in a major city in eastern Germany. He lived in a quasi-commune with other squatters in a house and was unemployed: "And after that [the fall of the iron curtain] it was just total collapse. So...for ten years, I was busy with... being anti, basically ((laughs))." Later, at the end of the 1990s, he started working freelance and doing several jobs (e.g., in construction and as a stagehand), including catering for different regional organizers and concert hosts. His contacts within the local music scene helped him considerably. Initially, his startup as a self-employed person was motivated by the pressure the employment agency exerted:

....at that time, we did not become self-employed because...we had the idea to build up a business, we had been looking for a way to escape the clutches of public employment service ((both laughing)) after uh... ten years of unemployment or not knowing which way to go.

Hence, the beginning of his business was rather unsystematic, and he started without having a plan, as a greenhorn, so to speak. Over time, his current catering company developed, which employs four to five people. His clients are primarily larger concert agencies and tour operators, for whom he provides the tour catering. In this context, it is important to mention a social aspect-his employees include several people he has known for many years. Some of them might have difficulty finding similar jobs in the "free" labor market, especially since Hans offers his employees a relatively large amount of freedom and "takes care" of them. This has been seen in the case of employees who have lost their driver's license, but continue to be employed or hired freelance, even though having a driver's license is extremely important in the (touring) catering business.

As for his motives, independence and autonomy are central aspects of his narrative. He started not only to free himself from the public employment agency but also to avoid becoming part of the industrial machinery (Fabrikräderwerk). However, he wound up entering the daily "rat race" of entrepreneurship, as he calls it. His early years as a self-employed person were financially precarious, and the growth of the company inevitably increased the bureaucratic burden. After a tax audit a few years ago, Hans was forced to hire some of his former freelance employees permanently. Subsequently, the reciprocal effect of incoming orders and monthly (wage) costs seem to have become a burden. In the past, he could simply turn down orders; he now feels obliged to achieve a certain monthly turnover. This demand for constant income is also due to his family situation, which has changed over time. Being a father of a 15-year-old boy and having a family alters daily routines and demands a stable income: "but when there's a family, it's a whole different thing. The business must be running somehow, right?" Therefore, before the COVID-19 outbreak, his will to lead a largely autonomous life collided with economic and bureaucratic necessities, especially health in- 
surance. However, we cannot discuss this in detail here, although there is a considerable body of data on it.

For Hans, who was working in the event sector, the outbreak of the COVID-19 pandemic was quite naturally followed by an immediate and very sudden end to all activities. Within weeks, most festivals, concerts, and scheduled tours were canceled, and his turnover fell to almost zero. However, at this point, the solidarity and support of friends or customers came into play. Friends ordered catering for smaller weddings, anniversaries, private events, and other outdoor events that were possible under "corona circumstances" during the summer. Although Hans was very optimistic and had a somewhat positive but pragmatic outlook on the whole situation at the beginning of the pandemic, his attitude seemed to change during autumn 2020. As he is running out of savings and forced to file for social welfare, he finds himself back in the institutional scheme he once wanted to escape. Another factor of uncertainty is the employer-employee relationship. COVID-19 affects the employees of Hans' catering company, as they are working short hours. Furthermore, Hans is unsure whether his employees will still be willing to work for him after extended periods in this status.

In addition to these fears and difficulties, another factor played an important role in the narrative of Hans and his catering company: being prepared for whatever might happen. Hans was well equipped in the sense of having financial savings, which means that initially, COVID-19 was perceived as less of a threat from a financial standpoint. However, as the pandemic and our inquiry moved on, the financial situation caused by the crisis worsened. On a later occasion, after our second interview, Hans told us that he was planning to file for social welfare (which he had always ruled out before), primarily because the situation has worsened. Scheduled concerts and the orders that accompanied them were still canceled. From Hans' viewpoint, the missing (proper) funding forces self-employed individuals to find regular jobs, whereas big companies (e.g., large concert agencies) can extend their credit line easily. Nevertheless, the idea of taking a smaller job was rejected by him, as it would mean losing time for his other project.

Even more important than his (constantly shrinking) savings is his "escape plan" or "plan B," which existed before the COVID-19 outbreak. Hans bought an old inn in the country some time ago and is currently restoring it. The inn and its grounds will be his future home, as well as a restaurant, a space for recreation, and a venue that could host artists, seminars, and other types of gatherings. Part of this plan is to turn his original business over to someone else and withdraw from the organizational side:

Well, rock'n'roll is a nice experience, and it's also fun. And it's a big family...so it's nice, but it's also incredibly exhausting, you know?...When you're at the venue, you work 16 hours, 18 hours a day. And I believe that at some age, I no longer have to do this to myself.

His strategy to escape from the daily "rat race" and structural obstacles has become even more important. Similar to another case (Case \#1, Tom), Hans has framed the COVID-19 pandemic as an opportunity to do something different or be freed from the burden of day-to-day business:

Apart from that, I can say that I am...I have been, over the years, when the machinery has always been running, when events have taken place all the time, and 
you ask yourself at certain times of the year or on certain days, "When you will ever again spend a day without a concert?" like December 25 or bank holidays, and so on. And so, it partly was also a relief not to have to do this as every year, as usual. And yes, Corona gave me the chance to continue my work here [at the construction site].

\section{Case \#3: Rosie}

Rosie was born in 1971 in the former GDR. After she finished school but had not sought any subsequent training or work, she was forced to apply for the only remaining positions at VEB Kombinat Robotron, the largest computer manufacturer in the GDR. She began a vocational training program there as a metalworker but only worked for Robotron for a short period before fleeing to West Germany via Prague in 1989. Soon after she arrived in the Federal Republic of Germany, she started working for a company there. This job (producing shades and marquees) was not only physically exhausting but she was also humiliated by her superiors. As a result, she found another job at an environmental technology office. The working conditions were better, and the staff consisted mainly of students, foreigners, and people from the Eastern part of Germany. These years, during the early 1990s, seem to have been shaped by experiences with degradation at work and social exclusion:

It was so racist, also towards the people from the Eastern part [of Germany]. It was my first personal contact with people when I noticed "there are several sensitivities here, you don't diminish them..." So, eventually, this system simply pissed me off. I didn't become comfortable with the Westerners...you were sitting in a pub, and they heard how you talk, your dialect, then you were, of course, the "Ossi" [a person from the former GDR], the freeloader who scrounges from everybody.

Eventually, Rosie moved back to eastern Germany and worked as a "day laborer," to quote her own words (e.g., cleaning, catering, and flea markets). In 1994, she began running a small business selling clothes and accessories at fairs. During the first few years after the political change, she traveled to Asia frequently, primarily to India, Nepal, and Thailand. Over time, she began importing clothing and accessories from these countries and selling them at markets, and started her shop in a university town in eastern Germany. After giving up this store a few years ago, she established a similar retail shop at her place of residence in another city in eastern Germany. However, it was not as profitable as her former business, resulting in a heavier workload and precarious financial situation. Rosie describes the phase when her business ran "smoothly" as her "golden times" compared to today's rather tense state.

Before the COVID-19 outbreak, she continued to travel to India and Thailand to buy and import goods to Germany. Over the years, she established a very well-organized network of manufactures and "knows her way around." These almost 30 years of traveling, bargaining, and buying in Asia are very important to her as she compares cultures:

...this is actually my favorite kind of business, you know...Because I started there as a little girl, and they [the merchants and manufacturers] said to me, "Do your stuff, but you might buy only ten necklaces this time...not twenty. Take it easy! Others have done that already." Very old men, they are mostly men I have to deal with there. They practically taught me how to do business. But, maybe it's an Asian... a different 
mercantile perspective. And, unfortunately, you can't practice that around here.

Returning to the subject of motives, a central reason seems to be the possibility of avoiding the "machinery" and, at least partially, bureaucratic procedures, as well as gaining autonomy.

And that's probably the main reason why you're self-employed. Because you... probably want a bit more of yourself...I can't even imagine being somewhere else again; that would be difficult ((MT laughs)). That somebody tells me what to do... And that [autonomy] is probably the basic idea.

Besides the will to lead an autonomous life, Case \#3 shows an interesting attitude of refusal. For example, although Rosie's business has not been very profitable in recent years, she is unwilling to introduce fair-trade labels. Although her products would probably be considered fair-trade (following her interpretation), she refuses to "play this role." This attitude also seems to be reflected in her refusal, upon starting her business, to accept public funding or cheap public loans, except for unemployment benefits for several months and a funding package by the Chamber of Commerce (German IHK): "I never wanted anything from them." This rather refractory mindset seems to be a very important motive for Rosie, who, as an entrepreneur, does not have to yield to mainstream practices of impression management, and does not have to rely on public loans.

Rosie was already in a rather precarious situation at the beginning of our inquiry. The pandemic was another hit to her financially stricken business. At first, she perceived various reasons for this situation. First, the increase in online trade has caused problems by gradually displacing smaller shops.
Second, there has been a general social change in consumption. Consumers, in particular, are increasingly aligning themselves with appropriate labels, especially regular customers. Refusing to use labels (such as fair-trade) could lead to a loss of customers. International trade has also changed to her disadvantage. Interestingly, increasing globalization has displaced her original niche, which has been taken over by large clothing chains whose scouts are operating in the same countries in Asia. This has led to some curious situations; for example, some time ago, she discovered a dress she had designed in a high-priced catalogue at about five times the price. A dressmaker in Nepal had simply sold "her" design due to a financial "emergency." Besides these changes, she faces very high overhead costs despite low turnover. All of these issues had made her think of ways to get out of the business before 2020. Now, facing the effects of the COVID-19 pandemic, problems are accumulating:

Prices go up steadily, my storage will also be more expensive next year...it's going straight up, so I have to think about that one, too. I have to find something smaller somehow, which is hard... because I can't afford it anymore then... pfff... well, I should have studied something proper.

After the first lockdown ended, during the summer of 2020, Rosie's business began doing quite well again. However, as autumn arrived, her turnover dropped again. At first, she could count on friends and regulars: "People checked on the community a bit more; that was quite good. When it was over [i.e., the first lockdown in spring], they came and made some purchases and showed solidarity."

However, some customers do not follow the COVID-19 regulations, and business owners like 
Rosie bear the consequences. Therefore, the new restrictions also cause uncertainty and fear at different levels:

There are a lot of deniers and refusers; they come in without wearing a mask, without asking if it's possible or not. So, even the fine of 60 Euros does not help. I have to pay two and a half thousand if some official comes in and checks; nobody cares, though.

As for her financial situation, Rosie (as well as Hans, Case \#2) is confronted with bearing the costs of health insurance while having little or no revenue. Due to the lack of alternatives, she is forced to pick up a regular job. As mentioned above, it is something she had previously ruled out:

But, the woman from health insurance told me that I definitely need a job. And I'll have to start looking for it in January. Then I'll go and get some work for a while. Keep my trading license as a small business. And then maybe I'll go on doing fairs. Because the costs are too high, it doesn't add up here.

Compared to the first two cases, Rosie expresses growing anxiety about the future. The idea of working a regular job seems to fuel this anxiety:

Rosie: I feel a bit nervous about it.

I: About what's coming next or because of taking up a job and so on?

Rosie: Of course. Sure. How that could go... doing housekeeping.

Rather frustrated, Rosie assesses her business and the closing of her shop:

You have to reinvent yourself somehow. And there is simply an oversupply of clothes and outfits. I mean... it's not really needed. We have too much of everything. It might be a wise decision to reduce it slowly. I've put a few offers on eBay now: "closing-down sale" blah, blah, blah, blah, blah, let's see if anyone is interested. I mean, there may be people who still need stock because they can't travel right now.

\section{Case \#4: Tamara}

Tamara was born in the early 1980s and grew up in the countryside, which she regards as a sheltered upbringing in the former GDR. During adolescence, she started to feel a sense of non-conformity that seems to have persisted:

Quite soon, I realized that I somehow had a strong desire for... from today's perspective, self-determination...quite soon, I realized that I somehow don't really fit in anywhere because I think about certain things differently or deal with certain things differently, and these things are not very well accepted.

After graduating from high school in the late 1990s, she worked at a theatre for some time, which she perceived as a "small window to the world," primarily because of the staff there. She met like-minded people there who were free spirits:

...not fitting into this classic role model... into this classic everyday life picture uh working Monday to Friday, working nine to five, having the weekend off, living in uh heterosexual family structures... just very different or very much very different.

She then moved to a major city in eastern Germany, enrolled in a university, and completed a humanities degree. Financing her studies with a small student loan and part-time jobs in restaurants, she started working for a public institution on a contract 
basis ("bogus" self-employment ${ }^{2}$ ) after the birth of her first child. During this period, she did not earn much money, which meant that she was covered by her husband's health insurance, for example. In the meantime, her second child was born; since her husband was the main breadwinner, Tamara was inevitably left to look after the children, which she increasingly perceived as a burden:

And then it came to a sudden interruption in all respects, a turning point... um... I separated from my husband, which was quite unexpected for him. I mean, it was obvious that I am not satisfied with the situation as it is, but I think he believed that it was mainly these daily routines that I am dissatisfied with, um... but I didn't feel like myself at all anymore...And I said to myself, "This can't go on like this, now it's over, over! That's it!"

After separating from her husband, she continued to work on a bogus self-employment basis, as well as at a permanent job for 20 hours a week at a restaurant. However, the workload of two jobs caring for her two children mostly alone led to a sense of overload, and "from a logistical point of view," it was "the worst case":

And I realized...that this is not going to work out in the long term because I simply do not have the strength and stamina to do it. And with the help of my new boyfriend... with whom I talked a lot about role models and sexuality and relationships, I decided to try sex work. In other words, pretty late. I was in my early thirties.

\footnotetext{
${ }^{2}$ Bogus self-employment or false self-employment is a form of "disguised" (Thörnquist 2011) employment. These self-employed workers often have only one client, and working conditions are similar to those of permanent employees. From the employer's point of view, the aim is to avoid taxes, employee rights, or collective agreements (Thörnquist 2011; 2015).
}

Starting small and keeping the restaurant job at the beginning, Tamara became a self-employed sex worker; she is now working as an escort in a brothel and as a sexual assistant. ${ }^{3}$ Tamara's motives for starting sex work are quite complex, so it is impossible to describe them in detail here. There is abundant room for further investigation of biographical aspects, especially considering the amount of data on hand. However, Tamara emphasizes how becoming a sex worker was her path to self-realization. She describes the first time she ever met a customer as follows:

\begin{abstract}
About an hour later, I walked out again, and it felt so incredibly good. It was great. I thought, "This is exactly the feeling you always imagined during your studies, how it could be when you are totally self-determined," and, well, how should I put it? I didn't do it for anyone else but me.
\end{abstract}

Her professional activity is socially stigmatized, and she tries to hide it in certain contexts. However, it is not always possible to do so (e.g., legal regulations force her to permanently carry an ID that identifies her as a sex worker). According to Tamara, the lack of knowledge and negative attitudes toward the profession in society make dealing with public institutions challenging. Working in a highly stigmatized sector or branch, Tamara is forced to keep up a kind of parallel identity, at least in some contexts:

When I'm asked what I'm doing, and it's in a context where I cannot speak openly about it, then yes, I always find some modifications that make it compatible with this very situation. This is absurd, of course, because I should be able to go anywhere and say, "That's

\footnotetext{
${ }^{3}$ Sexual assistance is a specialized sector of sex work mainly aiming at people with disabilities. For further information, see, e.g., Garofalo Geymonat (2019).
} 
what I do."...For instance, I certainly wouldn't tell anyone at my kids' school that I am a sex worker. I don't think that would be a good idea.

From the moment the pandemic hit Germany, the entire sex work industry was subject to a ban. Tamara, as well as all other sex workers, were required to stop working. This situation caused a whole range of problems, but we can only tackle a few of them in this paper. Given the stigma mentioned above, a crucial issue is the possible outing as a sex worker when filing for social benefits:

If you take the least strong restriction, so to speak, it is stigmatization. Because it is a forced outing you have to undergo if you apply for something like that. And many people just do this job secretly, uh, and get embarrassed to have to explain to their husband, ex-partner, mothers, whomever why they suddenly don't earn money anymore and suddenly have to fill out such applications and what kind of job title it says in there.

Furthermore, the vast majority of sex workers do not have health insurance. Although this issue does not apply in Tamara's case, it, nevertheless, illustrates the precarity of this line of work. An association of sex workers Tamara is involved in provides special training in hygiene; however, there is currently no way to implement such regularities and re-open the industry:

What's the difference to an erotic massage? There is no difference. But, massages are allowed. What is the difference between BDSM and a tattoo studio? There is none. And yet, everything that we dare to push forward gets rejected.

The ongoing prohibition of sex work leads to an uncontrolled black market with diverse negative effects:
You criminalize something, right? And when you do so, it becomes much, much more problematic. Because if something actually happens in such a situation, like an assault, like, uh, I don't know, like an illness. Well, like hell I am going to say: "This happened to me" because I did it illegally. And right now, that's not being considered at all.

In this case, the COVID-19 pandemic has led to the criminalization of a whole line of work, as there are no real alternatives for those who want to do this job the way Tamara does:

Well, there is no plan B for me, so to speak. Because plan B, C, D, E, F, and so on-I've already ticked everything off before. I am finally at a point where I can live and work the way I want to, right? No other option for me. If things really go on as they are at the moment, then I will work illegally. End of story.

As for her earnings, the situation is very tense. She still meets regular customers, even though it is illegal. Personal networks seem to have been more important than in the other cases in our study:

And if it wasn't for my private social network, I honestly wouldn't know how to pay for school lunch for my kids, for example. But, I do have my private network, which, uh, helps me, I have a partner who has a regular job and who hasn't lost his earnings. But, that makes me privileged, highly privileged. Only very few people in my line of work have that.

Before the COVID-19 outbreak, she openly spoke about the advantages of being a white, somewhat well-situated woman:

If I, as a woman, also have this, one might say, "power"... well, if you want to call it power, which is very 
questionable, uh, has "power" over the male sex, so to speak, due to certain role distributions and certain sexualities, why shouldn't I use this to my own benefit, on the one hand? And, on the other hand, perhaps also undermine it by using it to my advantage?

Despite being in a very precarious situation, she still emphasizes her attitude towards her profession and life, particularly when it comes to questions of legality and conformism:

I'm not going to let this self-determination, my life, and my being be taken away from me. That simply is against all my understanding of a decent life.

\section{Discussion}

The COVID-19 pandemic has had a considerable impact on the lives of all four individuals in our study. Within a few weeks, the caterer lost all orders, the sex worker was not allowed to work at all, the fitness instructor had to close his training space, and the retailer eventually decided to close her shop permanently. Our study revealed several parallels in the biographies and attitudes of the self-employed. However, the perception of the COVID-19 pandemic as a business disruption differed.

All four cases had an initially skeptical attitude towards the state and its institutions (e.g., the employment office, the tax office, and health insurance). This is evident in the rejection of business plans and public financial support, as well as a desire for independence from these institutions. Their low opinion of the state as a trustworthy authority might have been fuelled by their experience with the transformation of the former GDR and all of the accompanying uncertainties. Some of them also had negative experiences with public authorities, especially during adolescence. Growing up in the GDR and the experiences of working there at a young age, for instance, were mentioned several times in the interviews; even a certain feeling of being at home in the East (Ostgefühl), as Tamara put it. However, these findings must be interpreted with caution.

According to institutional theory, each individual is influenced and shaped by different institutional logics to varying degrees. This means that logics function as "guidelines on how to interpret and function in social situations" (Greenwood et al. 2011:318), even though they sometimes can be competing (Brandl and Bullinger 2017).

Due to their life experiences, all four cases, in particular Rosie, have distanced themselves from public logic. Perhaps, also, for this reason, their central individual logic is shaped by principles of self-realization and autonomy. With their self-employment, all four cases strive for the possibility of "individual freedom." Tom stated that he wants to pursue the activity that fulfills him and in which he can give something back to society. Hans and Rosie explained that they wanted to escape from the "rat race" and "wheelworks," and Tamara mentioned that she has finally found a way to live a self-determined life with which she can identify.

However, the COVID-19 pandemic has changed the situation for everyone. Before the outbreak of COVID-19, the logic of self-realization and autonomy was still somewhat compatible with necessary legal constraints, but business owners must now comply with multiple new restrictions. Doing this for the common good limits their autonomy and creates additional economic pressure. Consequent$l y$, the measures taken to contain the virus are not fully appreciated by all. One exception is Tom, who 
is a strong advocate of the legal restrictions linked to the COVID-19 pandemic and proactively took initiatives early on in his CrossFit-Box business. His ability to implement early measures was partly due to his contacts in the international community. This enabled Tom to evaluate the situation and react based on information from other countries, where tougher measures had already been taken before COVID-19 reached Germany. The others accept but do not agree with all the restrictions. Rosie criticizes the implementation and control of the rules, in particular, her obligation as a business owner to ensure compliance with the rules on the customer's side. At this point, the pressure and potential sanctions on shop owners do not seem to be fair to her. Tamara is highly motivated to comply with good hygiene measures, as they were quite naturally part of her business as a sex worker before the pandemic. However, she considers the absolute ban on working in her entire line of work to be unjustified. In her opinion, the new legal requirements will only force sex workers to disobey and lead to the criminalization of this activity in the long term. Nevertheless, none of the four cases are "corona deniers." All of them support the restrictions, despite the restrictions causing financial problems for some of them, as they are aimed at protecting the common good.

At this point, we observe an interesting paradox. Our cases are strongly oriented towards the logic of the common good, perceiving themselves as anti-materialistic, caregivers, or protectors of the vulnerable. For example, Hans retained one of his employees after he lost his driving license, despite it being one of the basic requirements for being a caterer. From an economic viewpoint, this would not be rational. From the perspective of institutional theory, this is an example of reacting to multiple and incompatible logics. As self-employed, they seek to achieve both financial independence and social impact by intentionally incorporating economic and social principles. By doing so, they are continuously forced to fight against pressures stemming from capitalist logic and embrace tensions other business owners normally seek to minimize. The social logic of health protection has suddenly become the dominant logic determining business and daily life, thereby displacing the logic of profit maximization. Consequently, some people who have adopted social logic, as in our four cases, are suffering due to the current situation. The conflict for organizations confronted with hybrid logic has been thoroughly examined in previous research (e.g., Kraatz and Block 2008; Reay and Hinings 2009; Greenwood et al. 2011; Besharov and Smith 2014; Gümüsay, Smets, and Morris 2020). However, beyond the existing literature, our study provides insights into how self-employed individuals deal with hybrid and changing institutional logics, leading to a conflict between their desire to lead an autonomous life and defend social principles.

On the other hand, our study shows how entrepreneurs with a strong individual desire for self-realization and autonomy constantly challenge existing social or cultural hegemonies by distancing from certain logics. These demarcations thus constitute the basis of "new" identities in Laclausian terms (Laclau 1990:9, 39; Reckwitz 2008:77-81). Tom consciously distances himself from a fixation on purely material values, and by taking a different stance and opposing (seemingly) universal hegemonies, he emphasizes anti-materialistic and people-centered values. Hans questions the centrality and dominance of work and, at the same time, reflects on his entrapment in the processes and structures. Rosie rejects certain forms of marketing and refuses common labels. And finally, Tamara associates her work with the idea of liberation from a life determined 
by others, which-in her line of work-also implies distancing oneself from social conventions.

Brandl and Bullinger (2017) have pointed out that, in the case of conflicting logic, the individual response corresponds to a process of "self-verification" (Brandl and Bullinger 2017:187). In this process, the logic that is more important for the respective identity prevails. This can be observed in the case of Rosie, for example, whose refusal to accept labels and marketing opposes the idea of selling goods and insofar the identity of being a retailer. Her attitude, however, ultimately dominates. This may even lead to distancing from other identities, just as mentioned above and as described by Brandl and Bullinger, as well (2017).

Concerning the COVID-19 pandemic, all four cases reacted with conformism during the first lockdown, as the federal restrictions fit their core principles of the common good. Furthermore, supporting compliance with the new regulations reflects the basic principle of solidarity in their communities. Friends and regular customers helped them buffer economic hardships, especially at the beginning of the COVID-19 pandemic. Although this helped during the first lockdown, solidarity certainly has limits and is not perceived as a solution to overcome the crisis. One could assume that public support takes effect at this point. However, as for COVID-19 aid programs, our cases draw a critical picture. Whether it is the consistent rejection of public funding due to skepticism about possible demands for repayment, as in Tom or Rosie's case, or a lack of programs for specific niches, as in Tamara's case, public funding plays a minimal role in our cases. The problem of sex workers not being included in the current COVID-19 aid programs may be linked to the fact that sex work, although it is a historically long-established institution, is a very ambivalent- ly discussed and stigmatized occupational field in Europe (Kilvington, Day, and Ward 2001; Weitzer 2018; Grittner and Walsh 2020). With our case study, we would like to emphasize the seriousness of the situation for many of those affected. Marginalized in two ways, sex workers are often foreign women without permanent residence or health insurance. According to a press release by the Federal Statistical Office in Germany in July 2020, only $19 \%$ of all officially registered sex workers have German citizenship (Statistisches Bundesamt 2020). The closure of brothels not only means financial losses for them but in some cases, even the beginning of homelessness. However, Tamara, due to her relatively stable situation and social network, has not suffered this extremely precarious situation.

Without sufficient financial support, it is all the more interesting that across the four cases, which were similarly affected by the COVID-19 restrictions, different assessments of the situation were expressed. The self-employed who already had a "plan B" or "escape plan" before the outbreak of the pandemic perceived this event as a less dramatic disruption, and framed it as an opportunity to leave the "wheelworks" of daily business and turn to other business activities. However, those without alternative plans experienced particular economic pressure from legal regulations accompanying the outbreak. Consequently, and from an economic viewpoint, all of our cases could use the strategy of having something to fall back on, including those who were working in a seemingly safe sector. With increasing economic pressure and uncertainty linked to the second lockdown, evaluations of the situation slightly changed and led to a wider range of response strategies, ranging from conformism to the deliberate undermining of certain rules and measures, up to neglecting and decoupling. 
In a wider context, our four cases significantly differ from the rather few existing qualitative case studies on "successful," "traditional," and prototypical entrepreneurs and how they are depicted-often as excessively working (Duchek 2018), passionate (Lombardi et al. 2021), and highly self-confident, emphasizing the strong desire for success and an orientation towards entrepreneurial goals, even at a young age, paired with a very strong tendency towards perfectionism (Göbel 2000). In contrast, the motives of our cases relate primarily to self-realization and autonomy, and also their relationship to work is by no means free of doubt. Though passion may play a big role in Tom's case, his standards for success-making people happy-are different from those of a prototypical entrepreneur. A surprising aspect is the experiences during childhood and adolescence; these support evidence from previous observations of rather typical entrepreneurs, showing that experiences at an early age can have a decisive influence on the later development becoming an entrepreneur and might lead to a need for autonomy and independence (e.g., Kets de Vries 1996).

\section{Conclusion, Limitations, and Future Research}

Our data offer a large amount of material for future research, including the topic of autonomy. The analysis of all four cases so far shows biographical simi- larities that seem to have shaped the personalities of self-employed individuals and entrepreneurs (e.g., their striving for autonomy is reflected in their orientation towards subcultures or "foreign" cultures). Moreover, it could be hypothesized that the resilience of individuals is related to their biographies and motives, especially their striving for autonomy. Another fruitful area for further work could be the role of networks and communities, especially in times of crisis.

We were able to identify differences, particularly in the interpretation of day-to-day economic challenges and coping strategies used to deal with them. Limiting our study to four (nevertheless extended) cases and covering very different economic sectors might be considered a limitation. However, it enables an in-depth and profound analysis of individual interpretations and actions in this very heterogeneous sample and brings to light numerous interesting results. Drawing on the perspective of entrepreneurs working in niches, the four cases sketched in our study highlight the variety of manifestations the COVID-19 pandemic can take. They furthermore show the diversity of reactions to this external shock and the understandings of the effects of this global pandemic within these specific fields of business. Nevertheless, the small sample size results in further research potential, and it certainly would be worth incorporating additional cases.

\section{References}

Ahbe, Thomas and Rainer Gries. 2006a. “Die Generationen der DDR und Ostdeutschlands. Ein Überblick [The Generations of the GDR and East Germany. An Overview]." Berliner Debatte Initial 17(4):90-109.
Ahbe, Thomas and Rainer Gries. 2006b. "Gesellschaftsgeschichte als Generationengeschichte. Theoretische und methodologische Überlegungen am Beispiel DDR [Social History as a Generation History. Theoretical and Methodological Consid- 
erations Using the Example of the GDR]." Die DDR aus generationengeschichtlicher Perspektive. Eine Inventur 2006:475-571.

Banalieva, Elitsa R. et al. 2017. "Communist Footprint and Subordinate Influence Behavior in Post-Communist Transition Economies." Journal of World Business 52(2):209-229. doi: 10.1016/j.jwb.2016.12.002.

Barrett, Rowena and Natalia Vershinina. 2017. "Intersectionality of Ethnic and Entrepreneurial Identities: A Study of PostWar Polish Entrepreneurs in an English City." Journal of Small Business Management 55(3):430-443.

Bartik, Alexander et al. 2020. "How Are Small Businesses Adjusting to COVID-19? Early Evidence from a Survey." National Bureau of Economic Research. doi: 10.3386/w26989.

Benkert, Volker. 2016. “Von der Breite und Tiefe ostdeutscher Kohortenprägungen. Warum die letzte DDR-Jugend keine Generation wurde [On the Breadth and Depth of East German Cohorts. Why the Last GDR Youth Did Not Become a Generation]." Pp. 3751 in Die Generation der Wendekinder. Elaboration eines Forschungsfeldes [The Generation of the Wendekinder. Elaboration of a Research Field], edited by A. Lettrari, C. Nestler, and N. Troi-Boeck. Wiesbaden: Springer VS.

Besharov, Marya L. and Wendy K. Smith. 2014. "Multiple Institutional Logics in Organizations: Explaining Their Varied Nature and Implications." Academy of Management Review 39(3):364-381. doi: 10.5465/amr.2011.0431.

Blokker, Paul and Bruno Dallago, eds. 2017. Youth Entrepreneurship and Local Development in Central and Eastern Europe. London: Routledge.

Blundell, Jack and Stephen Machin. 2020. Self-Employment in the Covid-19 Crisis: A CEP Covid-19 Analysis. London: London School of Economics and Political Science.

Bock, Karin. 2000. Politische Sozialisation in der Drei-Generationen-Familie: Eine qualitative Studie aus Ostdeutschland [Political Socialization in the Three Generation Family: A Qualitative Study from East Germany]. Vol. 103. Wiesbaden: VS Verlag für Sozialwissenschaften.

Brandl, Julia and Bernadette Bullinger. 2017. "Individuals' Considerations When Responding to Competing Logics." Journal of Management Inquiry 26(2):181-192. doi: 10.1177/1056492616677297.

Brewer, Jeremi and Stephen W. Gibson. 2014. Necessity Entrepreneurs: Microenterprise Education and Economic Development. Cheltenham: Edward Elgar Publishing.
Bruton, Garry D., David Ahlstrom, and Han-Lin Li. 2010. "Institutional Theory and Entrepreneurship: Where Are We Now and Where Do We Need to Move in the Future?" Entrepreneurship Theory and Practice 34(3):421-440. doi: 10.1111/j.15406520.2010.00390.x.

Caetano, Ana. 2015. "Personal Reflexivity and Biography: Methodological Challenges and Strategies." International Journal of Social Research Methodology 18(2):227-242. doi: 10.1080/13645579.2014.885154.

Cepel, Martin et al. 2020. "The Impact of the COVID-19 Crisis on the Perception of Business Risk in the SME Segment." Journal of International Studies 13(3). doi: 10.14254/2071-8330.2020/13$3 / 16$.

Crilly, Donal, Maurizio Zollo, and Morten T. Hansen. 2012. "Faking It or Muddling Through? Understanding Decoupling in Response to Stakeholder Pressures." The Academy of Management Journal 55(6):1429-1448. doi: 10.5465/amj.2010.0697.

Czarniawska, Barbara. 2004. "The Uses of Narrative in Social Science Research." Pp. 649-666 in Handbook of Data Analysis, edited by M. Hardy and A. Bryman. London: Sage.

Delmas, Magali A. and Michael W. Toffel. 2008. “Organizational Responses to Environmental Demands: Opening the Black Box." Strategic Management Journal 29(10):1027-1055. doi: 10.1002/ smj.701.

Denzin, Norman K. 2009. The Research Act: A Theoretical Introduction to Sociological Methods. Somerset: Taylor and Francis.

Deutsche Welle. 2020. "German Slaughterhouse Outbreak Crosses 1,000." Retrieved July 06, 2021 (https://p.dw.com/p/3e5We).

DiMaggio, Paul J. and Walter W. Powell. 1983. “The Iron Cage Revisited: Institutional Isomorphism and Collective Rationality in Organizational Fields." American Sociological Review 48(2):147-160. doi: 10.2307/2095101.

Duchek, Stephanie. 2018. “Entrepreneurial Resilience: A Biographical Analysis of Successful Entrepreneurs." International Entrepreneurship and Management Journal 14(2):429-455. doi: 10.1007/s11365-017-0467-2.

Eijdenberg, Emiel L. et al. 2019. "Entrepreneurial Activities in a Developing Country: An Institutional Theory Perspective." International Journal of Entrepreneurial Behavior \& Research 25(3):414-432. doi: 10.1108/IJEBR-12-2016-0418. 
Eisenhardt, Kathleen M. and Melissa E. Graebner. 2007. "Theory Building from Cases: Opportunities and Challenges." The Academy of Management Journal 50(1):25-32. doi: 10.2307/20159839.

Essers, Caroline and Yvonne Benschop. 2007. “Enterprising Identities: Female Entrepreneurs of Moroccan or Turkish Origin in the Netherlands." Organization Studies 28(1):49-69.

Essers, Caroline and Yvonne Benschop. 2009. "Muslim Businesswomen Doing Boundary Work: The Negotiation of Islam, Gender and Ethnicity within Entrepreneurial Contexts." Human Relations 62(3):403-423. doi: 10.1177/0018726708101042.

Fabeil, Noor F., Khairul H. Pazim, and Juliana Langgat. 2020. "The Impact of COVID-19 Pandemic Crisis on Micro-Enterprises: Entrepreneurs' Perspective on Business Continuity and Recovery Strategy." Journal of Economics and Business 3(2). Retrieved December 05, 2021 (https://papers.ssrn.com/sol3/papers.cfm?abstract_id=3612830).

Fairlie, Robert. 2020. The Impact of COVID-19 on Small Business Owners: The First Three Months after Social-Distancing Restrictions. Cambridge, MA: National Bureau of Economic Research.

Flick, Uwe. 2011. Triangulation. Wiesbaden: Springer Fachmedien.

Flick, Uwe. 2018. Doing Triangulation and Mixed Methods. Edited by U. Flick, 9th vol. Los Angeles, London, New Delhi, Singapore, Washington, Melbourne: Sage.

Garofalo Geymonat, Giulia. 2019. “Disability Rights Meet Sex Workers' Rights: The Making of Sexual Assistance in Europe." Sexuality Research and Social Policy 16(2):214-226. doi: 10.1007/ s13178-019-0377-x.

Gerpott, Fabiola H. and Alfred Kieser. 2017. “It's Not Charisma That Makes Extraordinarily Successful Entrepreneurs, but Extraordinary Success That Makes Entrepreneurs Charismatic." Managementforschung 27(1):147-166.

Göbel, Sigrun. 2000. "Klaus B: The Success Story of an Entrepreneur: A Case Study." European Journal of Work and Organizational Psychology 9(1):89-92. doi: 10.1080/135943200398085.

Görling, Stefan and Alf Rehn. 2008. "Accidental Ventures-A Materialist Reading of Opportunity and Entrepreneurial Potential." Scandinavian Journal of Management 24(2):94-102.

Greenwood, Royston et al., eds. 2008. The SAGE Handbook of Organizational Institutionalism. Los Angeles, London, New Delhi, Singapore: Sage.
Greenwood, Royston et al. 2011. "Institutional Complexity and Organizational Responses." Academy of Management Annals 5(1):317-371. doi: 10.5465/19416520.2011.590299.

Grittner, Alison L. and Christine A. Walsh. 2020. “The Role of Social Stigma in the Lives of Female-Identified Sex Workers: A Scoping Review." Sexuality \& Culture 24(5):1653-1682. doi: 10.1007/s12119-020-09707-7.

Gümüsay, Ali A., Michael Smets, and Timothy Morris. 2020. "'God at Work': Engaging Central and Incompatible Institutional Logics through Elastic Hybridity." The Academy of Management Journal 63(1):124-154. doi: 10.5465/amj.2016.0481.

Hite, Linda M. and Kimberly S. McDonald. 2020. “Careers after COVID-19: Challenges and Changes." $\mathrm{Hu}$ man Resource Development International 23(4):427-437. doi: 10.1080/13678868.2020.1779576.

Johnsen, Christian G. and Bent M. Sørensen. 2017. “Traversing the Fantasy of the Heroic Entrepreneur." International Journal of Entrepreneurial Behavior \& Research 23(2):228-244. doi: 10.1108/ IJEBR-01-2016-0032.

Kartseva, Marina A. and Polina O. Kuznetsova. 2020. "The Economic Consequences of the Coronavirus Pandemic: Which Groups Will Suffer More in Terms of Loss of Employment and Income?" Population and Economics 4(2):26-33. doi: 10.3897/popecon.4.e53194.

Kets de Vries, Manfred F. R. 1996. "The Anatomy of the Entrepreneur: Clinical Observations." Human Relations 49(7):853883. doi: 10.1177/001872679604900701.

Kilvington, Judith, Sophie Day, and Helen Ward. 2001. "Prostitution Policy in Europe: A Time of Change?" Feminist Review 67(1):78-93. doi: 10.1080/01417780150514510.

Kraatz, Matthew S. and Emily S. Block. 2008. "Organizational Implications of Institutional Pluralism." Pp. 243-275 in The SAGE Handbook of Organizational Institutionalism, edited by R. Greenwood et al. Los Angeles, London, New Delhi, Singapore: Sage.

Kubiak, Daniel. 2020. “Ostdeutsche Identität im Wandel der Zeiten. 30 Jahre und noch kein Ende [East German Identity through the Ages. 30 Years and No End Yet]." Pp. 189-198 in Regionalentwicklung in Ostdeutschland: Dynamiken, Perspektiven und der Beitrag der Humangeographie [Regional Development in East Germany: Dynamics, Perspectives, and the Contribution of Human Geography], edited by S. Becker and M. Naumann. Berlin, Heidelberg: Springer Berlin Heidelberg. 
Kubiak, Daniel and Weinel Martin. 2016. "DDR-Generationen Revisited - Gibt es einen Generationszusammenhang der 'Wendekinder?' [GDR Generations Revisited-Is There a Generational Connection between the 'Wendekinder?']." Pp. 107-129 in Die Generation der Wendekinder. Elaboration eines Forschungsfeldes [The Generation of the Wendekinder. Elaboration of a Research Field], edited by A. Lettrari, C. Nestler, and N. TroiBoeck. Wiesbaden: Springer VS.

Kuckartz, Udo and Stefan Rädiker. 2019. Analyzing Qualitative Data with MAXQDA: Text, Audio, and Video. Cham: Springer.

Laclau, Ernesto. 1990. New Reflections on the Revolution of Our Time. London: Verso.

Leitch, Claire M. and Richard T. Harrison. 2016. "Identity, Identity Formation and Identity Work in Entrepreneurship: Conceptual Developments and Empirical Applications." Entrepreneurship \& Regional Development 28(3-4):177-190. doi: 10.1080/08985626.2016.1155740.

Lettrari, Adriana, Christian Nestler, and Nadja Troi-Boeck, eds. 2016. Die Generation der Wendekinder: Elaboration eines Forschungsfeldes [The Generation of the Wendekinder: Elaboration of a Research Field]. Wiesbaden: Springer VS.

Lombardi, Rosa et al. 2021. "Strategic Entrepreneurship." Management Decision 59(5):1069-1084. doi: 10.1108/MD-10-2019-1416.

Maclean, Mairi, Charles Harvey, and Lindsay Stringfellow. 2017. "Narrative, Metaphor and the Subjective Understanding of Historic Identity Transition." Business History 59(8):1218-1241. doi: 10.1080/00076791.2016.1223048.

Meyer, John W. and Brian Rowan. 1977. "Institutionalized Organizations: Formal Structure as Myth and Ceremony." American Journal of Sociology 83(2):340-363. doi: 10.1086/226550.

Natow, Rebecca S. 2020. "The Use of Triangulation in Qualitative Studies Employing Elite Interviews." Qualitative Research 20(2):160-173. doi: 10.1177/1468794119830077.

Oliver, Christine. 1991. "Strategic Responses to Institutional Processes." Academy of Management Review 16(1):145-179. doi: 10.5465/amr.1991.4279002.

Ozasir Kacar, Sibel and Caroline Essers. 2019. “The Interplay between Identity Construction and Opportunity Structures: Narratives of Turkish Migrant Women Entrepreneurs in the Netherlands." International Small Business Journal: Researching Entrepreneurship 37(7):713-731.
Patton, Eric and Steven H. Appelbaum. 2003. "The Case for Case Studies in Management Research." Management Research News 26(5):60-71.

Paul, Ruxandra. 2020. “Europe's Essential Workers: Migration and Pandemic Politics in Central and Eastern Europe during COVID-19." European Policy Analysis 6(2):238-263. doi: 10.1002/epa2.1105.

Pécoud, Antoine. 2004. "Entrepreneurship and Identity: Cosmopolitanism and Cultural Competencies among GermanTurkish Businesspeople in Berlin." Journal of Ethnic and Migration Studies 30(1):3-20. doi: 10.1080/1369183032000170141.

Portuguez Castro, May and Marcela G. Gómez Zermeño. 2020. "Being an Entrepreneur Post-COVID-19-Resilience in Times of Crisis: A Systematic Literature Review." Journal of Entrepreneurship in Emerging Economies 13(4). doi: 10.1108/JEEE-07-2020-0246.

Ratten, Vanessa. 2020. "Coronavirus (Covid-19) and Entrepreneurship: Cultural, Lifestyle, and Societal Changes." Journal of Entrepreneurship in Emerging Economies 13(4). doi: 10.1108/JEEE06-2020-0163.

Reay, Trish and C. R. Hinings. 2009. "Managing the Rivalry of Competing Institutional Logics." Organization Studies 30(6):629652. doi: 10.1177/0170840609104803.

Reckwitz, Andreas. 2008. Subjekt. Bielefeld: transcript.

Rukti Tanaya, Dhayita and Fandis Ekyawan. 2020. “Empowerment Strategy on Micro, Small, and Medium Enterprises (MSMEs) during COVID-19 Pandemic in Indonesia: A Case Study of BRI Microfinance Center." E3S Web of Conferences 202:3022. doi: 10.1051/e3sconf/202020203022.

Sarasvathy, Saras D. 2001. "Causation and Effectuation: Toward a Theoretical Shift from Economic Inevitability to Entrepreneurial Contingency." The Academy of Management Review 26(2):243-263.

Schediwy, L., P. V. Bhansing, and E. Loots. 2018. “Young Musicians' Career Identities: Do Bohemian and Entrepreneurial Career Identities Compete or Cohere?" Creative Industries Journal 11(2):174-196. doi: 10.1080/17510694.2018.1489197.

Schütze, Fritz. 1983. "Biographieforschung und narratives Interview [Biography Research and Narrative Interview]." neue praxis 13(3):283-293.

Shafi, Mohsin, Junrong Liu, and Wenju Ren. 2020. "Impact of COVID-19 Pandemic on Micro, Small, and Medium-Sized 
Enterprises Operating in Pakistan." Research in Globalization 2:100018. doi: 10.1016/j.resglo.2020.100018.

Shepherd, Dean A. and Trenton Williams. 2020. "Entrepreneurship Responding to Adversity: Equilibrating Adverse Events and Disequilibrating Persistent Adversity." Organization Theory 1(4). doi: 10.1177/2631787720967678.

Slay, Holly S. and Delmonize A. Smith. 2011. "Professional Identity Construction: Using Narrative to Understand the Negotiation of Professional and Stigmatized Cultural Identities." Human Relations 64(1). doi: 10.1177/0018726710384290.

Spurk, Daniel and Caroline Straub. 2020. “Flexible Employment Relationships and Careers in Times of the COVID-19 Pandemic." Journal of Vocational Behavior 109:103435. doi: 10.1016/j.jvb.2020.103435.

Stake, Robert E. 2013. Multiple Case Study Analysis. New York, London: Guilford Publications.

Statistisches Bundesamt. 2020. “Ende 2019 rund 40400 Prostituierte bei Behörden angemeldet. Pressemitteilung Nr. 286 vom 30. Juli 2020 [Around 40,400 Prostitutes Registered with the Authorities at the End of 2019. Press Release no. 286 from July 30, 2020]." Retrieved December 22, 2020 (https://www.destatis.de/DE/Presse/Pressemitteilungen/2020/07/PD20_286_228.html).

Su, Jing, Qinghua Zhai, and Tomas Karlsson. 2017. “Beyond Red Tape and Fools: Institutional Theory in Entrepreneurship Research, 1992-2014." Entrepreneurship Theory and Practice 41(4):505-531. doi: 10.1111/etp.12218.

Thörnquist, Annette. 2011. "False Self-Employment: A Topical but Old Labor Market Problem." Pp. 101-129 in Precarious Em- ployment in Perspective. Old and New Challenges to Working Conditions in Sweden, edited by A. Thörnquist and Å.-K. Engstrand. Brussels: Peter Lang.

Thörnquist, Annette. 2015. “False Self-Employment and Other Precarious Forms of Employment in the 'Grey Area' of the Labour Market." International Journal of Comparative Labour Law and Industrial Relations 31(4):411-429.

Vadi, Maaja. 2018. "Snapshots of the Transformation in Central and Eastern Europe." Journal of East European Management Studies 23(4):702-712. doi: 10.5771/0949-6181-2018-4-702.

Weitzer, Ronald. 2018. “Resistance to Sex Work Stigma.” Sexualities 21(5-6):717-729. doi: 10.1177/1363460716684509.

Welter, Friederike, David Smallbone, and Nina Isakova, eds. 2006. Enterprising Women in Transition Economies. Florence: Taylor and Francis.

Wicks, David. 2001. “Institutionalized Mindsets of Invulnerability: Differentiated Institutional Fields and the Antecedents of Organizational Crisis." Organization Studies 22(4):659-692. doi: 10.1177/0170840601224005.

Wijaya, Oscarius Y. A. 2020. "The Impact of Covid-19 on Micro, Small, and Medium Enterprises (MSMEs) in East Java Province, Indonesia and Strategies for Overcoming: Ad Interim." Journal of Talent Development and Excellence 12(2s):3454-3469.

Yin, Robert K. 2018. Case Study Research and Applications: Design and Methods. Los Angeles, London, New Delhi, Singapore, Washington, Melbourne: Sage.

\section{Citation}

Tümpel, Markus and Pia Cardone. 2022. "“If Things Really Go On as They Are at the Moment, Then I Will Work Illegally. End of Story.' Pandemic Realities in Marginalized Entrepreneurships." Qualitative Sociology Review 18(1):74-95. Retrieved Month, Year (http://www.qualitativesociologyreview.org/ENG/archive_eng.php). DOI: https://doi.org/10.18778/1733-8077.18.1.04 